\title{
Japan joins efforts to patent cDNA clones
}

Tokyo

A Japanese genomics company, funded jointly by government and industry, has filed patent applications for more than 6,000 full-length human complementary DNA (cDNA) clones from various tissues, including the ovary, placenta and brain.

If it is successful, the Helix Research Institute plans to seek similar patents in the United States and Europe. But industry analysts say the Japanese Patent Office may be reluctant to award patents, pointing out that, although 700 of the clones are thought to correspond with genes that express membrane and secretory proteins, this alone would not satisfy the criteria of a patented invention. The functions of the remaining cDNA clones have not been specified.

The daily newspaper Yomiuri Shinbun reported last week that Helix - a joint venture between the Ministry of International Trade and Industry and ten private companies - applied for the patents in July. Helix hopes to produce, and possibly patent, a fur- ther 20,000 full-length human cDNA clones over the next two years, in collaboration with other companies and research institutes, possibly through a consortium.

Helix's move reflects its concern over growing competition from US biotechnology ventures, such as Incyte, which are accelerating their efforts to clone full-length human cDNAs.

In a bid to preserve open access to this information, the US National Institutes of Health is creating a public repository for fulllength human cDNAs to provide the research community with genetic sequences and clones (see Nature 401, 418; 1999).

Japan's cDNA project, which is led by Tokyo University, is aiming to sequence 30,000 cDNA clones - more than 20 per cent of expressed human genes - by 2001.

But Japan is falling behind the rest of the world in patenting genes, according to Hitoshi Watanabe, an executive director of Helix. A sense of urgency among researchers and industry has led to the government's decision to step up support for biotechnology (see Nature 400, 389; 1999).

"It is important to secure patents [on human genes] for future development of new pharmaceutical products as well as biomedical research," says Watanabe.

Watanabe declines to elaborate on the filed patents, other than saying that the cDNAs were divided into several groups. But sources close to the company confirm that three patents were filed, one of which is for a set of 200 full-length cDNA clones, corresponding to genes that express membrane and secretory proteins.

The second patent is for a set of 850 fulllength cDNA clones, 500 of which are also believed to express membrane and secretory proteins. The third is for the remaining 5,000 or so full-length cDNAs, although their functions are not known.

"We wouldn't have filed the patents if we thought there was no chance of them being approved," says Watanabe. But he admits he does not know how the applications will fare, as this is the first attempt to patent fulllength human cDNAs in Japan. Asako Saegusa

\section{US provides funding for sequencing rice genome}

Washington

The US government has awarded $\$ 12.3$

million to The Institute for Genomic

Research (TIGR) in Rockville, Maryland, and a consortium of universities to finance the country's component of an international effort to sequence the rice genome.

TIGR will receive $\$ 7.2$ million over three years, with another $\$ 5.1$ million going to Clemson University in South Carolina, Cold Spring Harbor Laboratory in New York, and Washington University in St Louis,

Missouri.

Between them, the institutions plan to sequence $\mathbf{5 0}$ million of the $\mathbf{4 3 0}$ million DNA base pairs estimated to make up the rice genome. They will begin with the 24 million bases in chromosome 10 , which has been allocated to the United States.

Although the rice genome was initially due to be completed by 2008, Japan, which is leading the project, has announced that it is planning to provide additional funding to complete its own sequencing efforts by 2004 (see Nature 401, 102; 1999).

Ed Kaleikau, director of plant research at the competitive grants office of the US Department of Agriculture (USDA), said that the US push would follow from the existing effort to sequence the genome of the model plant Arabidopsis, due to be completed by the end of next year.

"We're using a standard approach that

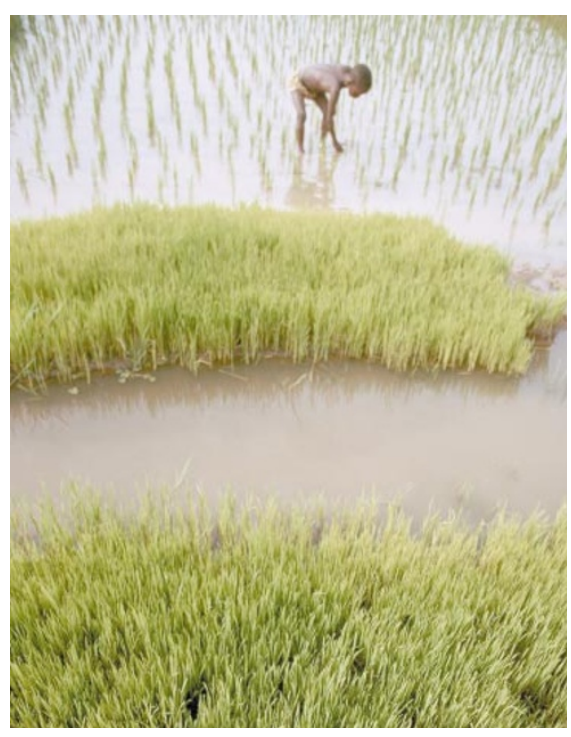

Take your pick: US efforts may focus on the indaco strain that is prevalent outside Japan.

builds on the strengths of the human and Arabidopsis [genome sequencing] projects," he says. USDA and the National Science Foundation (NSF) will each contribute $\$ 6$ million to the project, with another $\$ 300,000$ coming from the Department of Energy.

The international project will use a conventional approach to find the sequence of japonica rice, which is a commercially important strain.
Celera, the Rockville-based genesequencing company run by Craig Venter, has boasted that it could sequence the rice genome more rapidly than the publicly funded project, using its 'shotgun' approach (see Nature 398, 545; 1999). But a spokesman for Celera says that it is likely to concentrate on the genome of indaco rice, another important strain.

Indaco is the prevalent strain grown outside Japan and, according to Kaleikau, China has said that it will study it, rather than japonica rice, when it sequences chromosome 4 of the rice genome for the project.

Earlier this month, the NSF announced $\$ 60$ million of research grants under the second year of its plant genome project. These show that the agency plans to support genomics research in a wide range of commercially important plants, including multi-million dollar awards for research on potatoes and loblolly pine trees, as well as wheat, maize and Arabidopsis.

The NSF also said it would support a \$5.3 million Arabidopsis information resource, to be hosted jointly by the Carnegie Institution's Department of Plant Biology at Stanford University, California, and the National Center of Genome Resources at Santa Fe, New Mexico, which will disseminate data on the plant's genome. Colin Macilwain 